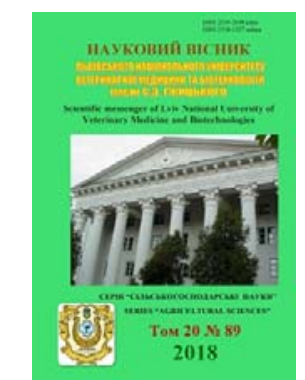

Науковий вісник Дьвівського націонадьного університету ветеринарної медицини та біотехнологій імені С.3. Гжицького

\author{
Scientific Messenger of Lviv National University \\ of Veterinary Medicine and Biotechnologies
}

UDC 636.5.083:628.9

\title{
Modern lighting systems for livestock enterprises
}

\author{
R.M. Muniv
}

Stepan Gzhytskyi National University of Veterinary Medicine and Biotechnologies Lviv, Ukraine

Article info

Received 24.09.2018 Received in revised form 24.10.2018

Accepted 25.10.2018

Stepan Gzhytskyi National University of Veterinary Medicine and Biotechnologies Lviv,

Pekarska Str., 50, Lviv, 79010, Ukraine.

Tel.: +38-067-370-43-92

E-mail:muniv@ukr.net

\begin{abstract}
Muniv, R.M. (2018). Modern lighting systems for livestock enterprises. Scientific Messenger of Lviv National University of Veterinary Medicine and Biotechnologies, 20(89),
\end{abstract} 127-132. doi: 10.32718/nvlvet8923

The constant rise in electricity prices, at least 10\% each year, makes livestock growers pay a lot of attention to finding ways to reduce their costs. Between different types of lighting, including in the field of agriculture, the leader in developed countries is LED. The main advantage of LED technology is energy efficiency. Properly selected intensity and duration of illumination have a very positive effect on health, fertility, well-being and productivity of dairy cattle and poultry. The 16-hour illumination regime at a level of 150-200 lux followed by 8-hour darkness leads to an increase in milk yield by 15\%, increased fertility, reduced intervals between calving and early diagnosis of animal diseases. We recommend to keep at least 150 lux for 16-18 hours, and then 8-6 hours of darkness for quality pig development. The farrowing room requires 16 hours of light followed by an 8-hour period of darkness. The minimum level of illumination for horses is 150-200 lux. This level of illumination coupled with the 16-hour lighting regime and the subsequent 8-hour darkness gives positive results in reproduction, making a significant impact on hormonal levels and fertility of horses. The traditional incandescent lamps, while performing their lighting functions, lose thermal energy production to 95\% of electricity, and only 5\% turns into useful light energy. When operating LED bulbs 40-50\% of electric energy is converted into light energy. Thus, the efficiency of LED lamps is 5-10 times higher than that of incandescent lamps. The biggest drawback of LED bulbs is their value, but the use of LED devices can save up to $70 \%$ of electricity. Energy-saving lamps save up to $80 \%$ of energy, sometimes even more. Obviously this becomes, if you translate interest in hryvnia. At a considerable cost of fluorescent lamps (LEDs) and LEDs during their work (from 6-12 thousand $h$ and up to 50 thousand h.) It is possible to save 165-1314 UAH. And this is on one lamp. The main difference is the price for the lamps themselves. LL costs about 25 UAH, and LED-80-250 UAH. The fairly high cost is compensated for a long time. Lamps can serve from 4 years $(L)$ to 12 years (LED lamps). In animal husbandry, as in one of the most energy intensive industries, the use of LED systems is most relevant, since it allows you to reduce the cost of production.

Key words: animal husbandry, lighting, energy saving, LED lamps.

\section{Сучасні системи освітлення тваринницьких підприємств}

\author{
Р.М. Минів \\ Львівський національний університет ветеринарної медицини та біотехнологій імені С.3. Гжицького, \\ м. Львів, Украйна
}

\footnotetext{
Постійне зростання цін на електроенергію, не менше ніж на 10\% кожного року, змушує тваринників приділяти велику увагу пошуку шляхів зниження ї̈ витрат. Поміж різних видів освітлення, у тому числі і в сфері сільського господарства, лідером у розвинених країнах є світлодіодне. Головною перевагою LED-технологій $\epsilon$ енергоефективність. Правильно вибрані інтенсивність $i$ тривалість освітлення вельми позитивно впливають на здоров'я, плодючість, благополуччя і продуктивність молочної худоби та птиці. Режим 16-годинного освітлення при рівні 150-200 люкс з подальшою 8-годинною темрявою призводить до збільшення надоїв молока на 15\%, підвищення плодючості, скорочені інтервали між отеленнями та ранньої діагностики хвороб тварин. Ми рекомендуємо підтримувати як мінімум 150 люкс протягом 16-18 годин, а потім 8-6 годин темряви для якісного розвитку свиней. Приміщення для опоросу потребує 16 годин світла з подальшим 8-годинним періодом темряви. Мінімальний рівень освітленості примімень для коней становить 150-200 люкс. Цей рівень освітленості в поєднанні з 16-годинним режимом освітлення і подальшою 8-годинною темрявою дає позитивні результати у в розмноженні, роблячи істотний вплив на гормональні рівні і плодючість коней. Традиційні лампи розжарювання при виконанні своӥх функцій по освітленню втрачають на продукування теплової енергії
} 
до 95\% електроенергї, і тільки 5\% - перетворюється в корисну світлову енергію. При експлуатації LED-лампочок 40-50\% електричної енергї̈ перетворюється в світлову енергію. Таким чином, ККД світлодіодних ламп в 5-10 разів вище, ніж у ламп розжарювання. Найбільший недолік LED-лампочок - ие їх вартість, однак використання LED-приладів дозволяє економити до $70 \%$ електроенергії. Енергозберігаючі лампи економлять до 80\% енергії, іноді навіть більше. Очевидним це стає, якщо перевести відсотки у гривні. При немалій вартості люмінесчентних ламп (ЛЛ) та LED за час їх роботи (від 6-12 тис. год і до 50 тис. год) можна зекономити 165-1314 грн. І ие на одній лампі. Основна відмінність - иіна за самі лампи. ЛЛ коштують приблизно 25 грн, а світлодіодні - 80-250 грн. Достатньо висока вартість компенсується в тривалому часі. Лампи можуть служити від 4 років (ЛЛ) до 12 років (LED-лампи). У тваринництві, як в одній із найбільш енергоємних галузей, застосування світлодіодних систем найбільш актуально, оскільки дозволяє знизити собівартість продукиії.

Ключові слова: тваринництво, освітлення, енергозбереження, LED-лампи.

\section{Вступ}

Останнім часом у всьому світі велику увагу приділяють енергозбереженню. Впровадження ресурсозберігаючих технологій виробництва, скорочення витрат на електроенергію, зниження навантаження на енергомережу позитивно впливають на ефективність сільськогосподарських підприємств та країни загалом.

На сьогодні в Україні модернізація систем освітлення не є приорітетом. Керівництво тваринницьких підприємств надає перевагу заміні ламп, що вийшли 3 ладу, на такі самі, хоча нові умови виробництва потребують і нових світлових рішень.

Постійне зростання цін на електроенергію, не менше ніж на 10\% кожного року, змушує тваринників приділяти велику увагу пошуку шляхів зниження іiі витрат. Чи не половина всіх витрат електроенергії у тваринницьких приміщеннях приходиться на їх освітлення. Наприклад, при застосуванні ламп розжарювання, на освітлення припадає $45-48 \%$ всіх витрат електроенергії, що у тваринницьких приміщеннях промислових розмірів складає 70-100 тис. кВт-год на рік, вартість якої становить близько 75-1010 тис. грн. То ж впровадження енергозберігаючих систем освітлення є одним 3 найбільш доступних способів зменшити загальні витрати електроенергії на підприємстві (Melnyk, 2010).

Поміж різних видів освітлення, у тому числі і в сфері сільського господарства, лідером у розвинених країнах $\epsilon$ світлодіодне. Головною перевагою LEDтехнологій є енергоефективність. Впровадження сучасних світлодіодних рішень забезпечує зниження енерговитрат на освітлення до 70\%. Крім того, приблизно на 20\% скорочуються витрати на технічне обслуговування систем освітлення.

\section{Результати та їх обговорення}

Освітлення відіграє велику роль у вирощуванні та продуктивності в тваринництві та птахівництві. Добре відомо, що світло є важливим фактором в птахівничому секторі. Невідповідний рівень освітленості або режим освітлення може негативно вплинути на здоров'я, продуктивність і благополуччя птахів (табл. 1).

\section{Таблиця 1}

Чинники освітлення пташників

\begin{tabular}{ll}
\hline \multicolumn{1}{c}{ Показник } & \multicolumn{1}{c}{ Характеристика } \\
\hline Оптимальний розподіл & Кури чутливі до світла. Отже, правильний розподіл світла і хороший рівень освітленості $є$ \\
& дуже важливими факторами, тому що правильний розподіл світла забезпечує оптимальний \\
& розподіл курей по всій площі будівлі. В результаті зменшується кількість вологих зон і знач- \\
& но знижуєтья ймовірність захворювання піддерматиту. \\
\hline Хороша система & Суттво важливим фактором для освітлення в будівлі $є$ якомога більш ефективне регулюван- \\
регулювання яскравості & ня його яскравості. Регульована яскравість освітлення дозволяє встановлювати будь- \\
& необхідний рівень освітленості в приміщенні. \\
\hline Мінімальне утворення & Правильний розподіл світла означає мінімальне утворення тіні. Курям не подобається пере- \\
тіні & бувати в темряві, тому важливо зводити до мінімуму зони тіні в будівлі. Наша компанія \\
& пропонує освітлення, що відповідає специфічним потребам домашньої птиці. Конструкція \\
& світильників забезпечує правильний розподіл світла при мінімальній кількості ламп і без \\
& тіней. Ідеальне рішення як для фермера, так і для домашньої птиці. \\
\hline Використання & У пташнику важливо використовувати високочастотне освітлення. Як зазначалося вище, \\
високочастотного & кури сприймають світло не так, як люди. При освітленні з частотою до 160 герц кури можуть \\
освітлення & сприймати світлові спалахи. Частота традиційного флуоресцентного освітлення становить 50 \\
& герц. Світлові спалахи створюють дуже неприємний для курей ефект «дискотеки». Світиль- \\
& ники також повинні бути стійкі до зміни кліматичних умов всередині будівлі. \\
\hline Рівень освітленості & Для домашньої птиці підходять кілька режимів освітлення. Вибір режиму залежить від виду \\
& домашньої птиці в пташнику. Мінімальний рівень освітленості для бройлерів становить \\
& 20 люкс на більш ніж $80 \%$ загальної площі будівлі. Аналогічні вимоги застосовні до курей- \\
& несучок, тоді як для племінних птахів потрібні 40-60 люкс. Залежно від конструкції будівлі \\
& ми раді надати вам інформацію про варіанти освітлення в пташнику. \\
\hline
\end{tabular}

Джерело: побудовано за даними (Ofitsiinyi veb-sait light-group) 
Крім забезпечення сприятливих умов праці, правильний рівень освітленості допомагає виявити будьякі ознаки хвороби на ранній стадії, стимулює зростання, істотно покращує добробут тварин і підвищує їх продуктивність.

Правильно вибрані інтенсивність і тривалість освітлення вельми позитивно впливають на здоров'я, плодючість, благополуччя і продуктивність молочної худоби.

Ймовірно, найвідомішим феноменом світла є його властивість управляти гормональними рівнями молочної худоби i, отже, позитивно впливати на надої молока, які можуть збільшуватися на 15\%. Мабуть, менш широко відомий той факт, що правильне однорідне освітлення в тваринницьких спорудах підвищує плодючість і робить позитивний вплив на еструс, а також спрощує спостереження. Використання правильних режимів освітлення і рівнів освітленості також сприяє скороченню інтервалу між отеленнями. Можливе також виявлення ознак хвороби на більш ранній стадії. Іншими словами, правильне освітлення забезпечить здоров'я і активність домашньої худоби.

Молочна худоба не відрізняє натрієву лампу високого тиску від металогалогенної лампи, тому важливе значення мають лише інтенсивність і тривалість освітлення. Дослідження показали, що мінімальний рівень освітленості повинен становити 150 люкс. 16годинний режим освітлення при мінімум 150 люкс і подальша 8-годинна темрява (максимум 5 люкс) забезпечать вищезгадані позитивні результати. Більш тривалі періоди освітлення означають меншу кількість гормону сну, поліпшення здоров'я і підвищення активності корів. Вищеописаний режим освітлення імітує довгі літні дні, коли підвищується природна активність корів, що сприяє більш високим надоями молока і кращого споживання корму.

Таким чином, режим 16-годинного освітлення при рівні 150-200 люкс 3 подальшою 8-годинною темрявою призводить до наступних результатів у молочних корів:

- збільшення надоїв молока на 15\%;

- $\quad$ підвищення плодючості;

- $\quad$ краще виявлення еструса;

- $\quad$ скорочені інтервали між отеленнями;

- $\quad$ рання діагностика хвороб.

Освітлення для свиней часто $є$ предметом дискусій. Мінімальну інтенсивність світла визначено на рівні 40 люкс. Проте, незалежні дослідження показують, що певний рівень освітленості має важливе значення для благополуччя тварин і буде сприяти кращим результатам.

У свиноматок хороше освітлення може стимулювати еструс. Самки розмножуються сезонно, а не протягом року. Природно, цей процес відбувається навесні. Короткі, темні дні уповільнюють його. Режим освітлення може продовжити короткі дні року. Ми рекомендуємо підтримувати як мінімум 150 люкс протягом 16-18 годин, а потім 8-6 годин темряви. Цей рівень світла і режим освітлення імітують найкращий час для еструсу (весна).
Приміщення для опоросу потребує 16 годин світла 3 подальшим 8-годинним періодом темряви. Для опоросу свиноматок, важливо стимулювати зростання поросят. Якщо періоди світла довгі (довші), поросята мають більше можливостей, щоб пити, так що кількість спожитого молока збільшується. Гарне освітлення призводить до кращого росту поросят. Це також збільшує шанси на виживання слабких поросят.

На додаток до режиму освітлення описаного вище, ми рекомендуємо середній рівень освітленості від 100 до 150 лк. Те ж саме відноситься і до відлучених поросят і свиней на відгодівлі. Збільшення довжини дня означає, що кожна тварина має безліч можливостей для використання поїлки або годівниці.

Дослідження показують, що освітлення в секторі відгодівлі є дуже важливим засобом збільшення споживання корму свиней, а це значить, що свині досягають своєї кінцевої ваги швидше. Це може бути досягнуто при рівні освітленості 100 лк. Хороший рівень освітленості також гарантує, що фермери можуть ефективно працювати. Легше працювати і виявити будь-які ознаки захворювання, коли рівень освітленості хороший. Тут доречним $є 16$ годинний освітлювальний режим, за яким слідують 8 годин темряви.

Ефективне освітлення конюшні є одним 3 тих елементів, які ніколи не повинні бути відсунуті на задній план. Хороший настрій, задоволені коні, приємне робоче середовище. Але цей ефект не відбувається сам по собі. Необхідно ретельно спланувати освітлення, щоб досягти цієї яскравої, комфортної атмосфери.

Незалежні дослідження показали, що кращий мінімальний рівень освітленості стаєнь для коней становить 150-200 люкс. Цей рівень освітленості в поєднанні $з$ 16-годинним режимом освітлення і подальшою 8-годинною темрявою дає позитивні результати.

Збільшення довготи дня за допомогою відповідного освітлення впливає на вироблення мелатоніну. Мелатонін також відомий як гормон сну. Світло пригнічує вироблення мелатоніну, а темрява прискорює iii. Іншими словами, більша кількість світла означає меншу кількість гормону сну i, отже, краще здоров'я i підвищену активність коней.

Коням також необхідний візуальний контакт. У темних стайнях менше можливості для (візуального) контакту 3 іншими кіньми. 3 цієї причини у коней можуть розвинутися стійлові вади, такі як розгойдування, обгризання стійла і повітряна прикуска, які найчастіше викликані нудьгою.

Освітлення також грає важливу роль в розмноженні, роблячи істотний вплив на гормональні рівні і плодючість коней. Можна збільшити довготу дня, встановивши 16-годинний режим освітлення при мінімальному рівні 150-200 люкс, тим самим запобігаючи загальновідомій зимовій млявості. При цьому у кобил з більшою ймовірністю настане еструс. У коней також відростає тонша зимова шерсть, що значно скорочує обсяги робіт і витрати, наприклад, на килимки і стрижку.

Особливо важливо забезпечити рівномірний розподіл світла на манежах для верхової їзд. Одним 3 найважливіших питань, що розглядаються при плану- 
ванні манежів, є запобігання утворенню тіней і світлових плям.

Таким чином, правильне освітлення в стайнях і на аренах для верхової їзди в поєднанні з хорошим рівнем освітленості і правильним режимом освітлення забезпечує наступні результати:

- поліпшення здоров'я і підвищення активності коней;

- більше можливостей для кращого візуального контакту;

- підвищена плодючість;

- тонша зимова шерсть;

- відсутність світлових плям на манежах для верхової їзди.

Для загального освітлення тваринницьких приміщень зазвичай використовують газорозрядні лампи типу ДРЛ (дугові ртутні лампи) потужністю 125, 250, 400 Вт. Виробництво цих ламп не трудомістке і нала- годжено майже усіма провідними світлотехнічними компаніями. До переваг ДРЛ відносять:

- високий рівень світлового потоку при відносно невеликих габаритах;

- тривалий строк експлуатації (не менше 12 тис. годин;

-можливість використання при низьких температурах, наприклад, в неопалюваних приміщеннях;

- низька ціна на пускорегулюючу апаратуру, та широкий ряд світильників.

Однак, існує і ряд недоліків, серед яких:

- потреба у спеціальних технологіях утилізації (зважаючи на наявність ртуті та люмінофору);

- низький рівень передачі кольору (близько 45\%);

- неможливість швидкого повторного включення (тільки через 10-15 хв);

-старіння (суттєве зниження рівня світлового потоку після 1000 годин експлуатаціï).

\section{Таблиця 2}

Основні експлуатаційні параметри ламп типу ДРЛ та їх світлодіодних аналогів

\begin{tabular}{ccccc}
\hline Тип & $\begin{array}{c}\text { Номінальна } \\
\text { потужність, Вт }\end{array}$ & $\begin{array}{c}\text { Споживча активна } \\
\text { потужність, Вт }\end{array}$ & $\begin{array}{c}\text { Середня тривалість } \\
\text { горіння, годин }\end{array}$ & Світловий потік, Лм \\
\hline ДРЛ-125 & 125 & 140 & 12000 & 6000 \\
ДРЛ-250 & 250 & 280 & 12000 & 13000 \\
ДРЛ-400 & 400 & 450 & 15000 & 24000 \\
СД аналог & 40 & 40 & До 100000 & 2500 \\
ДРЛ-125 & 80 & 80 & До 100000 & 5000 \\
СД аналог & & & \\
ДРЛ-250 & & &
\end{tabular}

Джерело: власні дослідження

Однією з найважливіших характеристик для освітлювального приладу є така характеристика, як світлова віддача, яка $є$ показником ефективності і економічності джерела світла.

Традиційні лампи розжарювання при виконанні своїх функцій по освітленню втрачають на продуку- вання теплової енергії до 95\% електроенергї, і тільки $5 \%$ - перетворюється в корисну світлову енергію. При експлуатації LED-лампочок 40-50\% електричної енергії перетворюється в світлову енергію. Таким чином, ККД світлодіодних ламп в 5-10 разів вище, ніж у ламп розжарювання (табл. 3).

\section{Таблиця 3}

Порівняльні характеристики основних параметрів різних типів освітлювальних приладів

\begin{tabular}{lccc}
\hline \multicolumn{1}{c}{ Базові характеристики } & Лампа розжарювання & Лампа люмінесцентна & Лампа світлодіодна \\
\hline Потужність & 75 Вт & 15 Вт & 10 Вт \\
Світловий потік & 700 лм & 700 лм & 800 лм \\
Світлова віддача & 0,12 лм/Вт & 46,7 лм/Вт & 80 лм/Вт \\
Термін служби & 1000 год & $\sim 800$ год & $\sim 50000$ год \\
Інфрачервоне випромінювання & Дуже високе & Мінімальне & Немає \\
Ультрафіолетове випромінюванняя & Прийнятне & Дуже високе & Немає \\
Тепловиділення & Високе & Середнє & Низьке \\
Вплив функції вмикання-вимикання & Скорочує термін служби & Скорочує термін служби & Не впливає \\
Ударостійкість & Низька (скло) & Низька (скло) & Висока (пластик) \\
Екологічність & Так & Ні & Так \\
ККд & Низький & Вередній & Немиє \\
Стробоскопічний ефект & Мінімальний & Високий & Низька \\
Інерційність & Низька & Висока & Так \\
Стійкість до перепадів температури & Ні & Ні & Висока \\
Стійкість роботи при низьких температурах & Середня & Низька & Так \\
Стійкість до вібрації & Ні & Ні & Немає \\
Навантаження на мережу & При пуску & При пуску & Висока \\
Вартість & Низька & Середня & \\
\hline
\end{tabular}

Джерело: побудовано за даними (Ofitsiinyi veb-sait masteram) 
Світлодіодне освітлення стає все більш поширеним та пріоритетним, позаяк вирішує не лише дизайнерські питання, але й питання енергозбереження, питання пожежної безпеки, вузькоспеціальні питання медицини та проблеми екології.

Найбільший недолік LED-лампочок - це їх вартість. Однак, з огляду на анонсований термін служби i постійне вдосконалення технологій, цей показник стає незначним, якщо врахувати той факт, що використання LED-приладів дозволяє економити до 70\% електроенергії. Особливо вражаючою стає ця економія на тлі постійно зростаючої потреби в електроенергії. Постійне нарощування енергетичних потужностей, у відповідь на зростаючі потреби, в більшості випадків призводить до забруднення навколишнього середовища та інших негативних наслідків (табл. 4).

\section{Таблиця 4}

Переваги світлодіодного (LED) освітлення

\begin{tabular}{|c|c|}
\hline Показник & Характеристика \\
\hline Економність & $\begin{array}{l}\text { при постійно зростаючих тарифах на електроенергію використання світлодіодних світильни- } \\
\text { ків приносить дуже відчутну економію! Досить згадати про те, що ККД звичайної лампочки } \\
\text { розжарення всього } 4 \% \text {, тоді як ККД світлодіода } 96 \% \text { ! }\end{array}$ \\
\hline $\begin{array}{l}\text { Тривалий термін } \\
\text { роботи }\end{array}$ & $\begin{array}{l}\text { важко повірити, але } \epsilon \text { вже світлодіоди, які можуть працювати неперервно до } 10 \text {-ти років. } \\
\text { Тобто, світлодіод пропрацює приблизно в } 100 \text { разів довше лампочки розжарення і в 5-10 } \\
\text { разів довше люмінесцентної (енергозберігаючої) лампочки. }\end{array}$ \\
\hline Надійність & $\begin{array}{l}\text { забудемо про тонку вольфрамову нитку! Випромінювання напівпровідника у сотні разів на- } \\
\text { дійніше і стійкіше до вібрації та механічних чинників. }\end{array}$ \\
\hline Екологічна безпека & $\begin{array}{l}\text { відсутність інфрачервоного, ультрафіолетового та радіоактивного випромінювання, не міс- } \\
\text { тить ртуті та інших шкідливих речовин - відсутня потреба в спеціальній утилізації. }\end{array}$ \\
\hline Мале тепловиділення & $\begin{array}{l}\text { під LED світильниками не нагріваються предмети, на які падає світло, що в свою чергу роз- } \\
\text { ширює діапазон їх використання. }\end{array}$ \\
\hline $\begin{array}{l}\text { Реальна } \\
\text { кольоропередача }\end{array}$ & $\begin{array}{l}\text { LED освітлення дуже схоже на денне. Тому ми бачимо реальний колір предметів. А кольорові } \\
\text { світлодіоди випромінюють чисті спектральні кольори, які дуже до вподоби дизайнерам. }\end{array}$ \\
\hline $\begin{array}{l}\text { Високий ступінь } \\
\text { захисту }\end{array}$ & LED світильники працюють в любих погодних умовах при температурі від -40 до +70 ㅇ․ \\
\hline $\begin{array}{l}\text { Абсолютна стійкість } \\
\text { до багаторазових } \\
\text { включень }\end{array}$ & $\begin{array}{l}\text { лампочки розжарення частіше всього перегоряють в момент включення, тоді як світлодіоду } \\
\text { це зовсім не властиво. }\end{array}$ \\
\hline $\begin{array}{l}\text { Відсутність стробос- } \\
\text { копічного ефекту }\end{array}$ & при падінні напруги в мережі пульсація світла відсутня. \\
\hline Рівномірне освітлення & $\begin{array}{l}\text { відсутність темних та світлих плям на горизонтальних та вертикальних площинах (комфортне } \\
\text { освітлення). }\end{array}$ \\
\hline
\end{tabular}
витрати на заміну ламп у важко доступних місцях, особливо якщо це зв'язано з викликом “автовишки”.

Таблиця 5

Економічна ефективність світлодіодних ламп

\begin{tabular}{lcc}
\hline \multicolumn{1}{c}{ Тип лампи } & Лампа розжарювання & СД лампа \\
\hline Споживання, Вт & 60 & 6,3 \\
Термін використання на добу, годин & 8 & 8 \\
Термін використання на рік, діб & 365 & 365 \\
Вартість 1 кВт електроенергії, грн & 2,18 & 2,18 \\
Загальна вартість електроенергії, грн & 381,9 & 40,1 \\
Вартість однієї лампи, грн & 5,58 & 39,9 (акційні) \\
Термін придатності однієї лампи, годин & 1000 & 25000 \\
Кількість замін за термін роботи однієї LED & 25 & 0 \\
Загальні витрати, грн & 521,4 & 80,0 \\
Економія за весь термін, грн & & 441,4 \\
\hline
\end{tabular}

Джерело: власні дослідження

Енергозберігаючі лампи економлять до 80\% енергії, іноді навіть більше. Очевидним це стає, якщо перевести відсотки у гривні. При немалій вартості люмінесцентних ламп (ЛЛ) та LED за час їх роботи (від
6-12 тис. год і до 50 тис. год) можна зекономити 1651314 грн. I це на одній лампі. Основна відмінність ціна за самі лампи. ЛЛ коштують приблизно 25 грн, а світлодіодні - 80-250 грн Достатньо висока вартість 
компенсується в тривалому часі. Лампи можуть служити від 4 років (ЛЛ) до 12 років (LED-лампи).

\section{Висновки}

Проведений аналіз показників освітлення тваринницьких підприємств виявив низький рівень якісних та кількісних показників вже існуючих освітлювальних установок. Використання світильників із застарілими джерелами не відповідає вимогам Міжнародного та Європейського стандартів внутрішнього освітлення робочих місць МКО/ICO (ISO 8995:2002 (Е) CIE 008/E-2001). Світлодіодне освітлення вирізняється від усіх традиційних технологій надійністю, значним терміном придатності, високою енергоефективністю та екологічністю. Найбільш цікавими на цей час для підприємств $€$ інтегровані системи освітлення на базі LED технологій, які дозволяють до 80 \% скоротити витрати електроенергії на освітлення.

Світлодіодні лампи - це спосіб зменшення негативного впливу на довкілля. Вони є більш екологічним джерелом освітлення приміщень, оскільки не містять ультрафіолетового випромінювання, яке при тривалому опроміненні сприяє розвитку меланоми, викликає опіки сітківки ока та прискорює процес старіння шкіри. У своєму складі люмінесцентні лампи містять ртуть, яку категорично не можна викидати при пошкодженні $з$ побутовими відходами, на відміну від світлодіодних. Замінивши люмінесцентні лампи, на менш шкідливі та економічні LED-лампи, можна суттєво скоротити електроспоживання.

\section{References}

Melnyk, V.O. (2010). Rizni kury - rizne svitlo. Nashe ptakhivnytstvo, 1, 23-26 (in Ukrainian).

Ofitsiinyi veb-sait light-group [Elektronnyi resurs]. Rezhym dostupu: https://www.light-group.com.ua (in Ukrainian).

Ofitsiinyi veb-sait masteram [Elektronnyi resurs]. Rezhym dostupu: https://masteram.com.ua/uk/articlesand-video/led-light (in Ukrainian). 